\title{
Revised Salmonella nomenclature: designation of Salmonella enterica (ex Kauffmann and Edwards 1952) Le Minor and Popoff 1987 sp. nov., nom. rev. as the neotype species of the genus Salmonella Lignieres 1900 (Approved Lists 1980), rejection of the name Salmonella choleraesuis (Smith 1894) Weldin 1927 (Approved Lists 1980), and conservation of the name Salmonella typhi (Schroeter 1886) Warren and Scott 1930 (Approved Lists 1980). Request for an Opinion
}

\author{
J. P. Euzéby \\ J. P. Euzéby. Fax: +33 5611939 75. e-mail: j.euzeby@envt.fr
}

Laboratoire de Bactériologie, École Nationale Vétérinaire, 23 Chemin des Capelles, F-31076 Toulouse cedex 3 , France

\begin{abstract}
The Request for an Opinion by Le Minor and Popoff 1987, proposing designation of ' Salmonella enterica' (ex Kauffmann and Edwards 1952) Le Minor and Popoff 1987 as the type and only species of the genus Salmonella Lignieres 1900 (Approved Lists 1980), has not been positively decided upon by the Judicial Commission. However, many bacteriologists use the name 'Salmonella enterica'. To avoid further confusion, it is requested to reject the name Salmonella choleraesuis (Smith 1894) Weldin 1927 (Approved Lists 1980), to recognize the species Salmonella enterica, to conserve the name Salmonella typhi (Schroeter 1886) Warren and Scott 1930 (Approved Lists 1980), and to emend the genus Salmonella with the establishment of a neotype species, Salmonella enterica.
\end{abstract}

Keywords: Salmonella, Salmonella enterica, Salmonella choleraesuis, nomenclatural changes, epitheta specifica conservanda
Salmonella strains have been isolated from humans and almost all animals throughout the world, and they cause many types of infection (self-limited gastroenteritis, severe gastroenteritis, typhoid fever, bacteraemia, abortion, meningitis, respiratory disease, cardiac disease, osteomyelitis and other local infections) (Gray, 1995).

The nomenclature of these bacteria has changed many times and is still not stable (Euzéby, 1997; Farmer, III \& Kelly, 1991; Gray, 1995; Le Minor et al., 1970, 1982b; Le Minor \& Popoff, 1987).

Five species are listed on the Approved Lists (Skerman et al., 1980, 1989): Salmonella arizonae (Borman 1957) Kauffmann 1964, Salmonella choleraesuis corrig. (Smith 1894) Weldin 1927 (type species of the genus),
Salmonella enteritidis (Gaertner 1888) Castellani and Chalmers 1919, Salmonella typhi (Schroeter 1886) Warren and Scott 1930 and Salmonella typhimurium (Loeffler 1892) Castellani and Chalmers 1919.

The DNA relatedness studies demonstrate that all Salmonella strains form a single DNA hybridization group with seven sub-groups (Le Minor et al., 1982a, 1986; Stoleru et al., 1976). So, according to the phylogenetic definition of a species (Wayne et al., 1987), all five species listed in the Approved Lists (Skerman et al., 1980, 1989) are members of a single genomospecies. All seven sub-groups can be differentiated by phenotypic properties (Le Minor et al., 1986), and Le Minor et al. (1982b, 1986) propose the name Salmonella choleraesuis (Smith 1894) Weldin 1927 for 
the single Salmonella species with the following seven subspecies: Salmonella choleraesuis subsp. arizonae (Borman 1957) Le Minor et al. 1985, Salmonella choleraesuis subsp. bongori Le Minor et al. 1985, Salmonella choleraesuis subsp. choleraesuis (Smith 1894) Weldin 1927, Salmonella choleraesuis subsp. diarizonae Le Minor et al. 1985, Salmonella choleraesuis subsp. houtenae Le Minor et al. 1985, Salmonella choleraesuis subsp. indica Le Minor et al. 1987, and Salmonella choleraesuis subsp. salamae Le Minor et al. 1985.

The names Salmonella choleraesuis subsp. arizonae, Salmonella choleraesuis subsp. bongori, Salmonella choleraesuis subsp. choleraesuis, Salmonella choleraesuis subsp. diarizonae, Salmonella choleraesuis subsp. houtenae and Salmonella choleraesuis subsp. salamae were validly published in 1985 (International Journal of Systematic Bacteriology, 1985). The name Salmonella choleraesuis subsp. indica was validly published in 1987 (International Journal of Systematic Bacteriology, 1987).

The name Salmonella choleraesuis can lead to confusion since the specific epithet is also the name of a serovar, Salmonella choleraesuis subsp. choleraesuis serovar Choleraesuis. So, in 1987, Le Minor \& Popoff (1987) requested that:

(1) The genus Salmonella consists of only one species and they proposed to use for this single species a name which has not been used previously for a serovar: 'Salmonella enterica' (ex Kauffmann and Edwards 1952) Le Minor and Popoff 1987, sp. nov., nom. rev.

(2) This unique species encompasses seven subspecies: 'Salmonella enterica subsp. arizonae', 'Salmonella enterica subsp. bongori', 'Salmonella enterica subsp. diarizonae', 'Salmonella enterica subsp. enterica', 'Salmonella enterica subsp. houtenae', 'Salmonella enterica subsp. indica' and 'Salmonella enterica subsp. salamae'.

(3) The names Salmonella choleraesuis corrig. (Smith 1894) Weldin 1927 (Approved Lists 1980), Salmonella enteritidis (Gaertner 1888) Castellani and Chalmers 1919 (Approved Lists 1980), Salmonella typhi (Schroeter 1886) Warren and Scott 1930 (Approved Lists 1980), and Salmonella typhimurium (Loeffler 1892) Castellani and Chalmers 1919 (Approved Lists 1980) are subjective synonyms of 'Salmonella enterica subsp. enterica'.

(4) The type strain of 'Salmonella enterica' (ex Kauffmann and Edwards 1952) Le Minor and Popoff 1987 , is the new type strain LT2 ${ }^{\mathrm{T}}$ (Lillengen strain type 2) $=$ CIP $6062^{\mathrm{T}}$.

Le Minor \& Popoff (1987) recognized the right of other bacteriologists to believe that the genus Salmonella should be composed of several species including Salmonella choleraesuis (type strain ATCC $13312^{\mathrm{T}}=$ NCTC $5735^{\mathrm{T}}$ ). So, to avoid an objective synonymy, they proposed that 'Salmonella enterica' be represented by a new type strain.
These proposals received unanimous support from the members of the Subcommittee on Enterobacteriaceae (Penner, 1988).

After this Request for an Opinion, the name Salmonella bongori (Le Minor et al. 1985) Reeves et al. 1989 , comb. nov. has been validly published for Salmonella choleraesuis subsp. bongori Le Minor et al. 1985 (Reeves et al., 1989; International Journal of Systematic Bacteriology, 1989).

If the name Salmonella bongori is not a problem, there is a lot of confusion with the name 'Salmonella enterica'.

On the one hand, this name is used by many working bacteriologists:

- it is used in reference documents such as the last revision of the Antigenic Formulas of the Salmonella Serovars (Popoff \& Le Minor, 1997);

- it is used in reference books such as the 2 nd edition of the Escherichia coli and Salmonella, Cellular and Molecular Biology (Neidhardt et al., 1996);

- and it is used in many scientific publications [for example, a search in the bibliographic database PubMed (http://www.ncbi.nlm.nih.gov/PubMed/) for Salmonella enterica as keyword finds 21403 documents and a search for Salmonella choleraesuis as keyword finds only 165 documents].

On the other hand, the Judicial Commission did not decide positively upon the request by Le Minor and Popoff, despite considerable agreement on the scientific validity, because of a reluctance to let Salmonella typhi be reduced to a serovar ("Salmonella enterica subsp. enterica' serovar Typhi) for reasons involving safety (Judicial Commission, 1991, 1995; Wayne, 1994). However, the Commissioners expressed a desire to see an alternative proposal published as a Request for an Opinion (Wayne, 1994).

The nomenclature should reflect advances in the science of taxonomy and the Judicial Commission should not be indifferent to the opinion of a large majority of bacteriologists.

To avoid further confusion, I request:

(1) The rejection of the specific name Salmonella choleraesuis corrig. (Smith 1894) Weldin 1927 (Approved Lists 1980) as an ambiguous name [Rule 56a (1) of the International Code of Nomenclature of Bacteria (Lapage et al., 1992)] because the specific epithet has been used with different meanings and thus has become a source of confusion.

(2) The recognition of the species Salmonella enterica (ex Kauffmann and Edwards 1952) Le Minor and Popoff 1987, sp. nov., nom. rev. The type strain is strain ATCC $13312^{\mathrm{T}}=$ NCTC $5735^{\mathrm{T}}$.

This species is divided into six subspecies: (i) a new subspecies, Salmonella enterica subsp. enterica (ex Kauffmann and Edwards 1952) Le Minor and Popoff 
1987 subsp. nov. (type strain ATCC $13312^{\mathrm{T}}=\mathrm{NCTC}$ $5735^{\mathrm{T}}$ ); and (ii) five subspecies which are new combinations [Rule 34a of the International Code of Nomenclature of Bacteria (Lapage et al., 1992)]: Salmonella enterica subsp. arizonae (Borman 1957) Le Minor and Popoff 1987, comb. nov. (type strain ATCC $\left.13314^{\mathrm{T}}=\mathrm{CIP} 8230^{\mathrm{T}}=\mathrm{NCTC} 8297^{\mathrm{T}}\right) ; \quad$ Salmonella enterica subsp. diarizonae (Le Minor et al. 1985) Le Minor and Popoff 1987, comb. nov. (type strain NCTC $10060^{\mathrm{T}}=$ CIP $\left.8231^{\mathrm{T}}\right) ;$ Salmonella enterica subsp. houtenae (Le Minor et al. 1985) Le Minor and Popoff 1987, comb. nov. (type strain CIP 8232T); Salmonella enterica subsp. indica (Le Minor et al. 1987) Le Minor and Popoff 1987, comb. nov. (type strain $\mathrm{K} 1240^{\mathrm{T}}=$ CIP $102501^{\mathrm{T}}$ ); and Salmonella enterica subsp. salamae (Le Minor et al. 1985) Le Minor and Popoff 1987, comb. nov. (type strain NCTC $5773^{\mathrm{T}}=$ CIP $8229^{\mathrm{T}}$ ).

(3) The conservation of the name Salmonella typhi (Schroeter 1886) Warren and Scott 1930 (Approved Lists 1980).

Clearly, the names Salmonella enteritidis, Salmonella typhi and Salmonella typhimurium, included in the Approved Lists (Skerman et al., 1980), were wrongly considered as species names. Historically, these species names were given to serovars by Kauffmann who defined the species as 'a group of related serofermentative phage types' (Kauffmann, 1961, cited by Le Minor \& Popoff, 1987). According to Le Minor \& Popoff (1987), this 'one serovar-one species' concept is untenable and the names Salmonella enteritidis, Salmonella typhi and Salmonella typhimurium are subjective synonyms of Salmonella enterica subsp. enterica. Actually, Salmonella enteritidis, Salmonella typhi and Salmonella typhimurium are no longer reported as species by the WHO International Collaborating Centre for Salmonella (Popoff \& Le Minor, 1997) or by most other reference laboratories, such as the Centre National d'Études Vétérinaires et Alimentaires, Laboratoire Central d'Hygiène Alimentaire (Brisabois et al., 1995).

However, the Judicial Commission is reluctant to let Salmonella typhi be reduced to a serovar because it is the causal agent of typhoid fever and because the use of the name Salmonella enterica subsp. enterica serovar Typhi could lead to accidents that may endanger health and life. The Judicial Commission can place a name on the list of conserved names without prejudice to the recognition or acceptance of its genetics relatedness to another taxon [for example, in spite of the scientific evidence which indicates the taxonomic relatedness of Yersinia pestis and Yersinia pseudotuberculosis, the name Yersinia pestis has been conserved for the plague bacillus (Judicial Commission, 1985)]. So, to reconcile the views of both the Judicial Commission and the working bacteriologists, it seems necessary to place the specific epithet typhi on the list of epitheta specifica conservanda.

On the other hand, the names enteritidis and typhimurium should apply only to serovar Enteritidis
(Salmonella enterica subsp. enterica serovar Enteritidis) and to serovar Typhimurium (Salmonella enterica subsp. enterica serovar Typhimurium), respectively.

(4) The emendation of the genus Salmonella Lignieres 1900 (Approved Lists 1980) with the establishment of a neotype species, Salmonella enterica (ex Kauffmann and Edwards 1952) Le Minor and Popoff 1987.

The genus Salmonella Lignieres 1900 (Approved Lists 1980) emend. Le Minor and Popoff 1987 consists of three species: (i) Salmonella bongori (Le Minor et al. 1985) Reeves et al. 1989; (ii) Salmonella enterica (ex Kauffmann and Edwards 1952) Le Minor and Popoff 1987, sp. nov., nom. rev. (type species of the genus); and (iii) Salmonella typhi (Schroeter 1886) Warren and Scott 1930 (Approved Lists 1980).

\section{References}

Brisabois, A., Fremy, S., Guignard, A., Moury, F., Oudart, C., Piquet, C. \& Pires Gomes, C. (1995). Inventaire des Salmonella, Inventory of Salmonella, 1992-1993. Paris: Centre National d'Études Vétérinaires et Alimentaires.

Euzéby, J. P. (1997). List of bacterial names with standing in nomenclature: a folder available on the Internet (http://wwwsv.cict.fr/bacterio/). Int J Syst Bacteriol 47, 590-592.

Farmer, J. J., III \& Kelly, M. T. (1991). Enterobacteriaceae. In Manual of Clinical Microbiology, 5th edn, pp. 360-383. Edited by A. Balows, W. J. Hausler, K. L. Herrmann, H. D. Isenberg \& H. J. Shadomy. Washington, DC: American Society for Microbiology.

Gray, L. D. (1995). Escherichia, Salmonella, Shigella, and Yersinia. In Manual of Clinical Microbiology, 6th edn, pp. 450-456. Edited by P. R. Murray, E. J. Baron, M. A. Pfaller, F. C. Tenover \& R. H. Yolken. Washington, DC: American Society for Microbiology.

International Journal of Systematic Bacteriology (1985). Salmonella choleraesuis subsp. arizonae, Salmonella choleraesuis subsp. bongori, Salmonella choleraesuis subsp. choleraesuis, Salmonella choleraesuis subsp. diarizonae, Salmonella choleraesuis subsp. houtenae and Salmonella choleraesuis subsp. salamae. In Validation of the Publication of New Names and New Combinations Previously Effectively Published Outside the IJSB, List no. 18. Int J Syst Bacteriol 35, 375-376.

International Journal of Systematic Bacteriology (1987). Salmonella choleraesuis subsp. indica. In Validation of the Publication of New Names and New Combinations Previously Effectively Published Outside the IJSB, List no. 23. Int J Syst Bacteriol 37, 179-180.

International Journal of Systematic Bacteriology (1989). Salmonella bongori (Le Minor et al. 1985) Reeves et al. 1989, comb. nov. In Validation of the Publication of New Names and New Combinations Previously Effectively Published Outside the IJSB, List no. 30. Int J Syst Bacteriol 39, 371.

Judicial Commission (1985). International Committee on Systematic Bacteriology. Opinion 60. Rejection of the name Yersinia pseudotuberculosis subsp. pestis (van Loghem) Bercovier et al. 1981 and conservation of the name Yersinia pestis (Lehmann and Neumann) van Loghem 1944 for the plague bacillus. Int J Syst Bacteriol 35, 540.

Judicial Commission (1991). International Committee on Systematic Bacteriology. Minutes 17(i) and 18(iii). Minutes of the 
Meetings, 14 September 1990, Osaka, Japan. Int J Syst Bacteriol 41, 185-187.

Judicial Commission (1995). International Committee on Systematic Bacteriology. Minute 7. Minutes of the Meetings, 2 and 6 July 1994, Prague, Czech Republic. Int J Syst Bacteriol 45, 195-196.

Lapage, S. P., Sneath, P. H. A., Lessel, E. F., Skerman, V. B. D., Seeliger, H. P. R. \& Clark, W. A. (editors) (1992). International Code of Nomenclature of Bacteria (1990 Revision). Bacteriological Code. Washington, DC: American Society for Microbiology.

Le Minor, L. \& Popoff, M. Y. (1987). Request for an Opinion. Designation of Salmonella enterica $\mathrm{sp}$. nov., nom. rev., as the type and only species of the genus Salmonella. Int $J$ Syst Bacteriol 37, 465-468.

Le Minor, L., Rhode, R. \& Taylor, J. (1970). Nomenclature des Salmonella. Ann Inst Pasteur 119, 206-210.

Le Minor, L., Véron, M. \& Popoff, M. (1982a). Taxonomie des Salmonella. Ann Microbiol (Inst Pasteur) 133B, 223-243.

Le Minor, L., Véron, M. \& Popoff, M. (1982b). Proposition pour une nomenclature des Salmonella. Ann Microbiol (Inst Pasteur) 133B, 245-254.

Le Minor, L., Popoff, M. Y., Laurent, B. \& Hermant, D. (1986). Individualisation d'une septième sous-espèce de Salmonella: $S$. choleraesuis subsp. indica subsp. nov. Ann Inst Pasteur/ Microbiol 137B, 211-217.

Neidhart, F. C., Curtiss, R., III, Ingraham, J. L. \& 7 other editors (1996). Escherichia coli and Salmonella, Cellular and Molecular Biology, 2nd edn. Washington, DC: American Society for Microbiology.
Penner, J. L. (secretary) (1988). International Committee on Systematic Bacteriology. Taxonomic subcommittee on Enterobacteriaceae. Minutes of the Meeting, 8 September 1986, Manchester, England. Int J Syst Bacteriol 38, 223-224.

Popoff, M. Y. \& Le Minor, L. (1997). Antigenic Formulas of the Salmonella Serovars, 7 th revn. WHO Collaborating Centre for Reference and Research on Salmonella. Institut Pasteur, Paris, France.

Reeves, M. W., Evins, G. M., Heiba, A. A., Plikaytis, B. D. \& Farmer, J. J., III (1989). Clonal nature of Salmonella typhi and its genetic relatedness to other salmonellae as shown by multilocus enzyme electrophoresis and proposal of Salmonella bongori comb. nov. J Clin Microbiol 27, 313-320.

Skerman, V. B. D., McGowan, V. \& Sneath, P. H. A. (editors) (1980). Approved lists of bacterial names. Int J Syst Bacteriol 30, 225-420.

Skerman, V. B. D., McGowan, V. \& Sneath, P. H. A. (editors) (1989). Approved Lists of Bacterial Names (Amended Edition). Washington, DC: American Society for Microbiology.

Stoleru, G. H., Le Minor, L. \& Lheritier, A. M. (1976). Polynucleotide sequence divergence among strains of Salmonella sub-genus IV and closely related organisms. Ann Microbiol (Inst Pasteur) 127A, 477-486.

Wayne, L. G. (1994). Actions of the Judicial Commission of the International Committee on Systematic Bacteriology on Requests for Opinions published between January 1985 and July 1993. Int $J$ Syst Bacteriol 44, 177-178.

Wayne, L. G., Brenner, D. J., Colwell, R. R. \& 9 other authors (1987). International Committee on Systematic Bacteriology. Report of the ad hoc committee on reconciliation of approaches to bacterial systematics. Int J Syst Bacteriol 37, 463-464. 